\title{
Earnings Management: Friend or Foe?
}

Judith A. Laux (E-mail: jlaux@ @oloradocollege.edu), Colorado College

\begin{abstract}
This study looks at some of the recent literature on quality of earnings and earnings management and debates the propositions that earnings management (1) is not new, (2) is an expected outcome of a GAAP approach to accounting, and (3) is not necessarily detrimental to efficient capital markets. It also offers suggestions for using earnings management in a positive fashion to influence the future of the profession.
\end{abstract}

\section{Introduction}

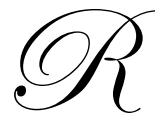

ecent accounting scandals have engendered something akin to hysteria in the accounting community and led to a mass of new literature on the quality of earnings and the earnings management phenomenon. At least one aspect of earnings management-income smoothing-has been known and debated since before Ronen and Sadan's 1981 Smoothing Income Numbers: Objectives, Means, and Implications, as attested to by their excellent summary of a vast number of empirical studies on the subject up to that time. In addition, general purpose financial statements prepared under GAAP guidelines invite flexibility in reporting economic well being that, coupled with market reliance on short-term profitability, makes earnings management practically irresistible. While fraudulent reporting undoubtedly results in capital market inefficiency, earnings management within GAAP guidelines has provided a pretty firm foundation for capital allocation for decades. Still, the wealth of new literature suggests that the question "earnings management: friend or foe?" is subject to debate.

\section{Recent Literature}

For a "pre-Enron" summary of the earnings management literature, see Healy and Whalen [1999] in which the authors look at studies of specific earnings management tools and the effect of earnings management on resource allocation. At that time, they urged the accounting profession to consider areas where standards could be altered to decrease the ability to manipulate earnings - places where it would make the most difference in assuring efficient resource allocation. In another review of earnings management, Dechow and Skinner [2000] contrast the perceptions of academics, practitioners, and regulators, finding that academics are less disturbed by earnings management (understating the problem due to the belief in efficient markets and difficulty in modeling earnings management) than are regulators and practitioners (who overstate the problem because of the inherent flexibility of GAAP, the existence of full disclosure, and the growing number of creative accounting innovations). In a similar vein, McDaniel, Martin, and Maines [2002] juxtapose financial literates with financial experts, finding that literates assess earnings quality differently than do experts; experts accent relevance more than do literates, and literates are more apt to accent nonrecurring items than are their expert counterparts. Finally, and most notably, all three of the major American Accounting Association publications devote entire issues to the subject of earnings quality/management-The Accounting Review [Vol. 77 Supplement, 2002], Issues in Accounting Education [Vol. 17, 2002], and Accounting Horizons [Vol. 17, 2003]. Many of the individual essays will be highlighted in the following sections on motivations for earnings management and the effect of earnings management on capital markets and resource allocation. 


\section{The Inevitability of Earnings Management}

The initial reaction of both accountants and non-accountants to earnings management is that it is "foe"accountants because of their attachment to reliability and non-accountants because of the association with fraud. One can make the argument, however, that it is a natural outcome of the flexibility (choices) inherent in GAAP and that, exercised with appropriate economic judgment, earnings management actually is "friend" to both accountants (who can better reflect economic reality) and non-accountants, including the stockholders whose wealth might be better maximized. In fact, given the financial manager's theoretical goal of stockholder wealth maximization, income smoothing (one form of earnings management) is desirable, because it reduces the variability in future expected cash flows, drives down the cost of equity (and debt), and maximizes share price. In addition, changes in compensation structures in recent years towards stock-based compensation have added the inducement to maximize short-term stock price. Matsumoto [2002] associates certain firm characteristics with the incentive to avoid negative earnings surprises. Finally, the capital market's accent on short-term profitability makes earnings management a way of life for the practitioner. Parfet, in "Accounting Subjectivity and Earnings Management: A Preparer Perspective" [2000, p. 483] contends: "Corporate preparers operate from a sense of obligation to produce continuous improvement in operating performance, steadily and reliably increasing financial returns, and long-term growth in shareholder value...[creating] a high-pressure working environment." He contrasts "bad" earnings management ("intervening to hide real operating performance") with "good" ("reasonable and proper practices") and calls attention to "the context in which decisions are made, where subtle effects from human perceptions and peer pressures, the complexity of combined factors, and a high-stakes business environment all impact good people who are trying to do their jobs with integrity." (p. 487) That leads us to the real issue: Earnings management as a continuum, with economic reality as reflected through appropriate GAAP-approved choices at one end and intentional revenue/asset overstatement (or expense/liability understatement), i.e., fraudulent reporting at the other. At what point on this continuum does earnings management interfere with capital market efficiency?

\section{Earnings Management and Capital Market Efficiency}

While many of the essays contained in the three special AAA issues mentioned earlier speak to the "how" of earnings management [Nelson et al, 2003; Sack, 2002; Swain et al, 2002; and Nelson et al, 2002, among others], at least one [Arya, Glover, and Sunder, 2003] asks the question, "Are Unmanaged Earnings Always Better for Shareholders?" They contend that "income manipulation is not an unmitigated evil; within limits, it promotes efficient decisions" (p. 111) and cite management's ability to distinguish transient changes in income from permanent income better than external users. (After all, the investing public doesn't really want to know what a firm made this year; they are really only interested in its promise for the future.) Hodge [2003] finds that, although perceived earnings quality has declined over time, the perceived relevance of financial information has actually increased. Thus, on one hand, earnings management seems foe; on the other it is friend. Clikeman [2002] recognizes the problems of measuring earnings for companies in the information age, a situation that, again, invites some type of earnings management by insiders who might have an "edge" in valuing a firm's future promise. If earnings quality is synonymous with repeatability/sustainability, then earnings management might be necessary to ensure quality, not in conflict with it. Finally, Entwistle and Phillips [2003] make laudable arguments for both sides of the relevance/reliability tradeoff and the manage-earnings/do-not-manage-earnings implications.

\section{Future Implications}

So how do we often arrive at the other end of the spectrum, where income smoothing and within-GAAP earnings manipulation cross the line to inappropriate revenue acceleration/recognition and other accounting improprieties? It is human nature to believe that, if exercising a little flexibility in accounting choices is good, then more must be better. Too many have slid down that slippery moral slope, and suddenly we find that we have lost credibility in the capital markets and face a new dawn with laws such as the Sarbanes-Oxley Act. Smith's 2003 editorial "A Fresh Look at Accounting Ethics (or Dr. Smith Goes to Washington)" suggests that the accounting profession must return to its traditional ethical values, but how does this relate to the earnings management debate? 
How do we restore "public confidence in [our]...service" [p. 48]? How do we "summon current and future accountants to [their] nobility" [p. 49]? Perhaps the answer lies not just in raising the ethical bar once more but also in alleviating the pressure Parfet referred to earlier by teaching our students about earnings management (vs. manipulation) and better arming them to share that dogma with their financial managers and other superiors. Finally, we must also do a better job of "marketing" to the investing public just what earnings management is (and, more importantly, is not). As we become clearer on those distinctions-and perhaps devoting entire scholarly issues to the debate is a good start - we will come closer to offering our students and external users a basis for renewed faith (and renewed accuracy) in accounting information.

\section{Suggestions for Future Research}

It would be quite useful to both accounting academicians and the investing public to have a "handbook" of earnings management techniques and a guide to how each individual industry approaches financial reporting. In addition, the auditing industry and the FASB should consider the benefits of including a judgment in the annual audit that rates a company's approach to reporting income (e.g., conservative, neutral, aggressive) in comparison to others in their industry. Future researchers may also want to investigate how the topic is handled differently in accounting texts and in the curriculum in general.

\section{References}

1. Arya, A., J. Glover, and S. Sunder, “Are Unmanaged Earnings Always Better for Shareholders?", Accounting Horizons (Supplement): 111-116, 2003.

2. Clikeman, P., "The Quality of Earnings in the Information Age", Issues in Accounting Education 17 (4): 411-417, 2002.

3. Dechow, P. and D. Skinner, "Earnings Management: Reconciling the Views of Accounting Academics, Practitioners, and Regulators", Accounting Horizons 14 (2): 235-250, 2000.

4. Entwistle, G. and F. Phillips, "Relevance, Reliability, and the Earnings Quality Debate", Issues in Accounting Education 18 (1): 79-92, 2003.

5. Healey, P. and J. Wahlen, "A Review of the Earnings Management Literature and Its Implications for Standard Setting”, Accounting Horizons 13 (4): 365-383, 1999.

6. Hodge, F., "Investors' Perceptions of Earnings Quality, Auditor Independence, and the Usefulness of Audited Financial Information", Accounting Horizons (Supplement): 37-48, 2003.

7. Matsumoto, D., "Management's Incentives to Avoid Negative Earnings Surprises", The Accounting Review 77 (3): 483-514, 2002.

8. McDaniel, L., R. Martin, and L. Maines, "Evaluating Financial Reporting Quality: The Effects of Financial Expertise vs. Financial Literacy", The Accounting Review 77 (Supplement): 139-167, 2002.

9. Nelson, M., J. Elliott, and R. Tarpley, "Evidence from Auditors about Managers' and Auditors' Earnings Management Decisions", The Accounting Review 77 (Supplement): 175-202, 2002.

10. , "How Are Earnings Managed? Examples from Auditors", Accounting Horizons (Supplement): 17-35, 2003.

11. Parfet, W., "Accounting Subjectivity and Earnings Management: A Preparer Perspective", Accounting Horizons 14 (4): 481-488, 2000.

12. Ronen, J. and S. Sadan, Smoothing Income Numbers: Objectives, Means, and Implications, Reading, MA: Addison-Wesley Publishing Co., 1981.

13. Sack, R., "Interstate Transport, Inc: A Case Study in Earnings Management", Issues in Accounting Education 17 (4): 369-388, 2002.

14. Smith, L., "A Fresh Look at Accounting Ethics (or Dr. Smith Goes to Washington)", Accounting Horizons 17(1): 47-49, 2003.

15. Swain, M., R. Allen, D. Cottrell, and K. Pexton, "TechMall.com: Revenue Recognition in the Internet Economy”, Issues in Accounting Education 17 (4): 389-400, 2002. 
Notes 